\title{
水田雑草イヌビエが獲得した化学防御システム 生合成遺伝子クラスターの進化起源はどこに?
}

植物の生産する低分子化合物のなかで，イネのモミ殼 から単離されたジテルペノイド化合物のモミラクトンは, 生物間コミュニケーションにおいて複数の生物学的な意 味をもつ化学防御物質と言える。モミラクトンの病害抵 抗性における機能としては，イネいもち病菌などの病原 菌の感染により，感染部位で生産が誘導され，病原菌の 生育を抑える抗菌活性を発揮することから，植物が生産 する抵抗性物質のファイトアレキシンとしてよく知られ ている。また，植物と植物の関係においては，周りの植 物の成長を妨げるアレロパシー物質としての機能ももつ ており，イネの根から放出されるモミラクトンによって， 周辺の雑草の生育が抑えられることも知られている ${ }^{(1)}$. さらに，近年，動物細胞に対する影響についても，モミ ラクトンの添加により細胞周期がストップしてしまい, 細胞の増殖が抑制されることが報告されており，抗がん 作用をもつ天然物としても期待されている(2).

さて，このような幅広い生物活性を有するモミラクト ンの生合成遺伝子は，高等真核生物では珍しい遺伝子ク ラスターをイネゲノム上に構成して存在している。同様 な生合成中間体をもつジテルペノイド植物ホルモンのジ ベレリンについては，その生合成遺伝子は染色体上に散 らばって存在しているが，モミラクトンの生合成遺伝子 クラスターは，栽培イネOryza sativaだけでなくOryza 属の野生イネ（O. rufipogonやO. punctataなど）にお いても保存されており, 進化的なモミラクトン生合成遺 伝子クラスター保持の分岐点が見えてきた (3). 今のとこ ろ, モミラクトンの生産能と遺伝子クラスターの存在に は相関があり，モミラクトンを生産するためには，なぜ だか遺伝子クラスターとしてゲノム上に遺伝子を維持す る必要があるようである。

筆者らは野生イネの研究を進めていたことをきっかけ に, 水田雑草のゲノムシーケンスを読み進めていた浙江 大学のLongjiang Fan教授とコラボレーションする機会 を得た。本稿で紹介するイヌビエEchinochloa crus-gal$l i$ は, その研究のなかで材料として用いられていた品種 の一つで，6倍体ゲノムをもつ。ゲノムシーケンスから は，3コピーあるゲノムセットのうち，一つにイネのモ ミラクトン生合成遺伝子と類似性の高い遺伝子群がクラ
スターを形成し保存されていることがわかった，イヌビ エで見つかったこのクラスターは, 図 1 に示すように, イネ 4 番染色体に存在するモミラクトン生合成遺伝子ク ラスターとは完全に一致するものではなくシンテニーが 低い. しかし，モミラクトンの炭素骨格であるピマラジ エンの合成酵素遺伝子 $K S L 4$ やミラクトン合成の最終 段階を担う $M A S$ 遺伝子に相当するイヌビエの遺伝子ホ モログは，イネと同じようにいもち病菌の接種によって 転写レベルで発現誘導を受ける。また，いもち病菌接種 後のイヌビエ葉身では，モミラクトンの誘導的な生産も 認められている (未発表デー夕)。その生産量は, イネ のそれと比較して微量ではあるものの, この結果から, イヌビエがイネと後述するハイゴケに続く第 3 のミラ クトン生産植物であることが明らかになった ${ }^{(4)}$.

イヌビエのモミラクトン生合成遺伝子クラスターは, 正確には個々の遺伝子機能の証明がなされていないの で「「クスター候補」であるが，その証明にはさほど 時間を要さないであろう。一方で，イヌビエのモミラク トン生合成遺伝子クラスター（候補）の形成は，いつ, どのように行われたのかを証明することは容易ではな い. 進化系統樹を頼りに，イヌビエクラスターの構成手 順が考察されている。イヌビエはイネやミナトカモジグ サとは離れてアワやトウモロコシのようなイネ科植物と 系統的にまとまるが，モミラクトン生合成酵素遺伝子に

\section{モミラクトン生合成遺伝子クラスター}
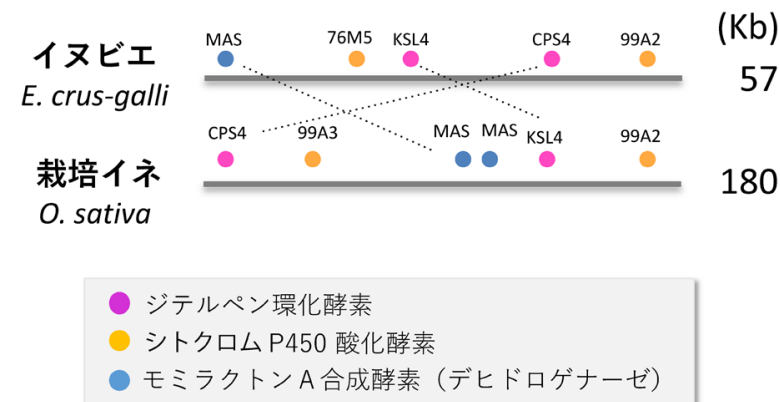

図1 -イヌビエと栽培イネのモミラクトン生合成遺伝子クラスター それぞれの染色体上にはアミノ酸レベルで類似性の高いモミラク トン生合成遺伝子が座乗するが，遺伝子の配置は異なっている。 
着目すると，イネのなかでもモミラクトンを合成する O. sativaに一番近くなる.このことは，モミラクトン 生合成遺伝子クラスターが, 多段階の遺伝子増幅と欠 落, そして現段階ではメカニズム不明の遺伝子水平伝播 を含むような，複雑なプロセスを経て構成された可能性 を暗示している．今後，さらに多くのシーケンス解析が 進み，モミラクトン生合成遺伝子クラスターを保持した 植物が発見されれば，より確からしいクラスターの起源 が見えてくるかもしれない.

イヌビエとイネを生態学的な観点で眺めてみれば，ヒ トの手によって作られた四角いリング（水田）のなかで 戦う $2 つ の$ 植物の攻防戦が垣間見られる. しかも, リン グサイドからセコンドの手厚いサポートを受けているイ ネに比べ，イヌビエはアウェーの戦いのようではない か. そのような状況でも，「雑草魂」でイネにダメージ を与えるイヌビエには，モミラクトンだけでなく，ほか の化学防御物質を利用する技もあることがわかってき た、ベンゾキサジノイドと呼ばれる化合物は，カビや昆 虫に対する防除活性をもっているが，植物に対しても生 育抑制効果が認められる。この化合物はトウモロコシや カラスムギで多く生産され, しかも生合成遺伝子群は, 遺伝子クラスターとして存在している. イヌビエに㧤い ても，ベンゾキサジノイドの生合成遺伝子クラスターが 見つかっており，シンテニーを保って存在していること から，こちらは交配可能な種間が存在したかもしれない 時代に, 水平伝播によりイヌビエの祖先に取り込まれた 可能性も否定できない. しかし, モミラクトンについて は，野生イネのなかでクラスター出現の起点が見られる ことから，イヌビエのクラスター出現とは関係なく，そ れぞれにクラスターを構成しモミラクトン生産能を獲得 したのではないかと考えられる.

イネとイヌビエ以外の植物については，アジア地域で 普通に生息し, 盆栽用のコケとして園芸店で取り扱われ ている蘚類ハイゴケ (Hypunum plumaeforme) が, モ ミラクトンを生産していることが2007年に報告され,
その生合成遺伝子の取得も進んでいる ${ }^{(5)}$. しかし, ハイ ゴケがモミラクトン遺伝子クラスターを保持しているの かどうかについては，まだ明らかにされていない。この ように，ハイゴケもモミラクトンを生産できることを考 え合わせると, イネとイヌビエは, 生物活性の強いモミ ラクトンという化学防御物質の生合成能を収斂進化によ りそれぞれ独立に獲得したものと思われる。

1) E. A. Schmelz, A. Huffaker, J. W. Sims, S. A. Christensen, X. Lu, K. Okada \& R. J. Peters: Plant J., 79, 659 (2014).

2) C. Park, N. Y. Jeong, G. Y. Kim, M. H. Han, I. M. Chung, W. J. Kim, Y. H. Yoo \& Y. H. Choi: Oncol. Rep., 31, 1653 (2014).

3) K. Miyamoto, M. Fujita, M. R. Shenton, S. Akashi, C. Sugawara, A. Sakai, K. Horie, M. Hasegawa, H. Kawaide, W. Mitsuhashi et al.: Plant J., 87, 293 (2016).

4) L. Guo. J. Qiu, C. Ye, G. Jin, L. Mao, H. Zhang, X. Yang, Q. Peng, Y. Wang, L. Jia et al.: Nature Communications, 8, 1031 (2017).

5) K. Okada, H. Kawaide, K. Miyamoto, S. Miyazaki, R. Kainuma, H. Kimura, K. Fujiwara, M. Natsume, H. Nojiri, M. Nakajima et al.: Sci. Rep., 3, 25316 (2016).

(岡田憲典, 東京大学生物生産工学研究センター)

プロフィール

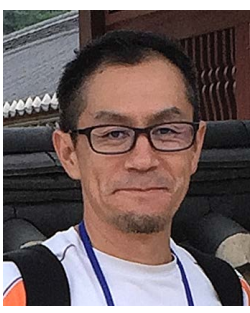

岡田 憲典 (Kazunori OKADA)

<略歴>1992年島根大学農学部生物資源 科学学科卒業 / 1998 年鳥取大学大学院連 合農学研究科博士課程修了/同年理化学研 究所基礎科学特別研究員 $/ 2000$ 年東京学 芸大学第三部生物学科助手 $/ 2003$ 年東京 大学生物生産工学研究センター助手 $/ 2013$ 年同准教授, 現在に至る<研究テーマと抱 負 >植物がつくりだす二次代謝産物の役割 や生き物との関係を追究し, 環境保全につ ながるような応用・利用に結びつける<趣 味 >トライアスロン（60歳までに鉄人に なることを予定)．今年はウルトラマラソ ンに挑戦し, そのうちアドベンチャーレー スもやってみたい

Copyright (C) 2018 公益社団法人日本農芸化学会 DOI: 10.1271/kagakutoseibutsu.56.526 